\title{
THE FIRST RECORD OF TINODES ANTONIOI BOTOSANEANU \& TATICCHI-VIGANÒ, 1974 (INSECTA, TRICHOPTERA) IN CROATIA WITH DNA BARCODING AND ECOLOGICAL DATA AND NOTICE OF BIODIVERSITY AND DISTRIBUTION OF THE GENUS TINODES IN CROATIA
}

\author{
Mladen Kučinić ${ }^{\text {, AnĐela Ćukušić }}{ }^{2}$, Martina Podnar ${ }^{2}$, \\ Miro Landeka ${ }^{3}$, Hrvoje Plavec ${ }^{4}$, Mladen Plantak ${ }^{5}$, \\ Nazymgul Akimbekova ${ }^{6}$ \& Sanja $\check{Z}_{\text {alac }}{ }^{7}$
}

\author{
${ }^{1}$ Department of Biology (Laboratory for Entomology), Faculty of Science, University of Zagreb, \\ Rooseveltov trg 6, 10000 Zagreb, Croatia \\ ${ }^{2}$ Croatian Natural History Museum, Demetrova 1, 10000 Zagreb, Croatia \\ ${ }^{3}$ Marina Tartaglie 2, 10 000, Zagreb, Croatia \\ ${ }^{4}$ Grožnjanska 18, 10000 Zagreb, Croatia
}

${ }^{5}$ Elektroprojekt, d.d., Civil and Architectural Engineering Department, Alexandera von Humboldta 4, 10000 Zagreb, Croatia

${ }^{6}$ S. Toraigyrov State University in Pavlodar, Kazakhstan

${ }^{7}$ Tuk Bjelopoljski 14, Plitvička jezera, 53230, Korenica, Croatia

Kučinić, M., Ćukušić, A., Podnar, M., Landeka, M., Plavec, H., Plantak, M., Akimbekova, N. \& Žalac, S.: The first record of Tinodes antonioi Botosaneanu \& Taticchi-Viganò, 1974 (Insecta, Trichoptera) in Croatia with DNA barcoding and ecological data and notice of biodiversity and distribution of the genus Tinodes in Croatia. Nat. Croat., Vol. 25, No. 1., 131-149, 2016, Zagreb.

The species Tinodes antonioi, a new species in the fauna of Croatia, was determined in northern Istria. The paper provides information about T. antonioi in Croatia (DNA barcode data, period of the finds, localities of the finds, numbers of males and females collected) as well as the biodiversity and distribution of the Tinodes genus in Croatia. A reference is made to the species endemic in Croatia, Tinodes andrasi, established to date at only one site in the south of Croatia (Konavle, Dalmacija).

Key words: caddisflies, Tinodes, molecular data, Istria, Dalmatia, Croatia

Kučinić, M., Ćukušić, A., Podnar, M., Landeka, M., Plavec, H., Plantak, M., Akimbekova, N. \& Žalac, S.: Prvi nalaz Tinodes antonioi Botosaneanu \& Taticchi-Viganò, 1974 (Insecta, Trichoptera) u Hrvatskoj s DNA barkod i ekološkim podacima i noticom na bioraznolikost i rasprostranjenost roda Tinodes u Hrvatskoj. Nat. Croat., Vol. 25, No. 1., 131-149, 2016, Zagreb.

Vrsta Tinodes antonioi, kao nova u fauni Hrvatske, zabilježena je po prvi puta u sjevernoj Istri. U radu se daju informacije o T. antonioi u Hrvatskoj (DNA barkod podaci, periodi nalaza, lokaliteti nalaza, broj prikupljenih mužjaka i ženki), kao i bioraznolikost i rasprostranjenost roda Tinodes u Hrvatskoj. Daje se osvrt i na endem Hrvatske, Tinodes andrasi, zabilježen samo na jednom lokalitetu u Hrvatskoj (Konavle, Dalmacija).

Ključne riječi: tulari, Tinodes, molekularni podaci, Istra, Dalmacija, Hrvatska

\section{INTRODUCTION}

Systematic research into Trichoptera fauna in Croatia started with the work of the Croatian Natural History Museum in Zagreb at the end of the $20^{\text {th }}$ century. Before that, 
research did not have a systematic character, although it had managed to record some very valuable faunistic and taxonomic results (RADOvanović, 1935; MARINKOvić-GospodNETIĆ, 1971; 1979) as far as the knowledge of Trichoptera fauna in Croatia is concerned. Limnological research, conducted vigorously in the streams of Croatia from the mid $20^{\text {th }}$ century also provided a partial insight into the composition and structure of caddisfly fauna, although these data were limited by the very research methods, which analysed only larvae for the determination of species, and no adult forms (MATONIČKIN, 1959, 1987; MatoničKin \& Pavletić, 1967; MatoničKin et al., 1971; Habdija, 1979, 1989; Habdija et al., 2003).

Research initiated by staff members of the Croatian Natural History Museum (F. Perović, M. Kučinić, I. Mihoci, M. Vajdić, B. Jalžić) and later by staff of the Faculty of Science of Zagreb University and other colleagues, has been directed in the last 20 or so years to the study of faunistic (KučInIĆ, 2002; Previšić et al., 2010; KučInIĆ et al., 2011a; 2014; 2015a; CERJANEC, 2012; ŠEMniČKi et al., 2012; ĆUK \& VuČKoviĆ, 2014) taxonomic (KučInić \& Malicky, 2002; Malicky et al., 2007; Kučinić et al., 2008; 2011b; 2013; WarinGER et al., 2009; OlÁH, 2010; 2011; Previšić et al., 2014a; VučKović et al. 2011) and phylogeographic features of caddisflies in Croatia (PREvišić et al., 2009; 2014b) as well as in neighbouring countries. Fellow researchers from abroad took part in this research, which covered parts of Bosnia and Herzegovina (Kučinić et al., 2011b; 2015b; Previšıć et al., 2014a; ViteceK et al., 2015c; Waringer et al., 2016; StAnić-Koštroman et al., 2012, 2015), Kosovo (IBrahimi et al., 2012; 2014; 2015; 2016), Serbia (WARInger et al., 2015) and Macedonia (KuČinić et al.,2016; ViteceK et al., 2015a; 2015b; WARINGER et al., 2016).

By very similar species, identification based on morphological diagnoses requires molecular analysis to confirm results or to speed it up. HeBert et al. (2003a; 2003b) proposed a relatively new method named "DNA barcoding" which use a robust primer set to amplify approximately 650-base pair (bp) region of the mitochondrial (mt) cytochrome-c oxidase subunit 1 ( $C O I$ ) gene to ensure rapid and accurate identification of a broad range of biological specimens. The divergences of this COI-5P gene fragment (DNA barcode region) enable the discrimination of closely related species in all animal phyla except the Cnidaria (Hebert et al., 2003b). The Barcode of Life project (BOLD) was proposed to promote DNA barcoding as a global standard for sequence-based identification of eukaryotes (Jinbo et al., 2011).

This molecular-based identification is not new for study of caddisflies (e.g. GísLason et al., 2015; GrAF et al., 2015; WARINGer et al., 2015; IbrAhimi et al., 2015, 2016; ViteceK et al., 2015a), but in Croatia for this group there is so far only one study based on DNA barcoding analysis (KučInIĆ et al., 2013).

At the beginning of 2014 the two-year implementation of the NIP project started, which covered research into 9 groups of animals, including Trichoptera. In the implementation of the NIP project, caddisflies were collected from 105 sites in various parts of Croatia and processed from a faunistic point of view. Not only were very many data collected that supplement our knowledge of the biodiversity and distribution of caddisflies in the inland, central mountain and Mediterranean areas, but a certain number of new species for the Croatian fauna were discovered (Kučınıć et al., 2015a; M. Kučinić unpublished data).This paper gives: 1. the finds of a new species for Croatian fauna, Tinodes antonioi; 2 . a review of this genus in Istria; 3 . the biodiversity and distribution of the Tinodes genus in Croatia. The first data about the genetic features of the species Tinodes antonioi established with mtDNA barcoding are provided, the finding sites, the number of males and females collected and photographs of the genitals of specimens collected in Croatia. 


\section{MATERIAL AND METHODS}

\section{Fieldwork}

In the context of the NIP project, collection of Trichoptera was carried out at the sites Marušića Stream and Mlini Stream (Fig. 1A, B). Both streams are located in the northern parts of Istria. Collection of the material took place two times during 2014 (August and September) and one time during 2015 (May). Each of the streams had two collecting sites, the first being the spring. The second site on the Marušića was located in the upper part of the stream, on a bridge about 150 metres from the spring (Fig. 1A). The second site on Mlini Stream was $1 \mathrm{~km}$ downstream from the source, on a bridge alongside a road off to Mlini (Fig. 1B). This site is subject to considerable anthropological impact, for in this part the stream has been partially hydrologically engineered. At each locality, collection of adults was implemented in daytime with an entomological net, for a period of 30 minutes, and at night with the use of a $15 \mathrm{~W}$ UV lamp, for a period of 90 minutes. All the material collected was stored in phials containing $96 \%$ alcohol. The specimens collected now form part of the NIP Trichoptera Collection kept in the Croatian Natural History Museum in Zagreb.

\section{Laboratory work}

Determination of the genus Tinodes material collected was conducted after MALICKY (2004), and females of the species T. antonioi after CiAnficconi et al. (1999). A systematic presentation of species of the genus Tinodes recorded in Croatia has been given after Morse (2016) and the division of Croatia into inland (Pannonian-peripannonian), upland or mountainous and Mediterranean parts is given after BerTić et al. (2001) (Fig. 2).

\section{Molecular analyses}

Tinodes specimens that were DNA barcoded in this study account for one specimen undoubtedly identified as T. antonioi, two similar but morphologically slightly different samples refer therefore to Tinodes sp., and four additional Tinodes species occurring in Croatia: T. braueri McLachlan, T. dives (Pictet), T. pallidulus McLachlan and T. waeneri (Linnaeus) (Tab. 1).

Whole genomic DNA was extracted from single leg using GenElute Mammalian Genomic DNA Miniprep kit (Sigma-Aldrich, Germany) according to the manufacturer's specifications and eluted in $100 \mu$ l of elution buffer. The remainder of the specimen was kept as a voucher in the Trichoptera DNA Barcode collection in the Croatian Natural History Museum in Zagreb.

For all specimens, full-length of DNA barcode region was amplified using LCO1490/ HCO2198 (Folmer et al., 1994) primer sets. The $50 \mu \mathrm{l}$ polymerase chain reactions (PCR) mixture contained 1 x Go Taq®Reaction Buffer (containing $1.5 \mathrm{mM} \mathrm{MgCl2}$, Promega), $0.2 \mathrm{mM}$ of each dNTP, $0.4 \mu \mathrm{M}$ of each primer, 1.25 units of Go Taq®DNA Polymerase (Promega) and $5 \mu \mathrm{l}$ of DNA eluate. PCR cycling conditions comprised an initial denaturation step $\left(94^{\circ} \mathrm{C}\right.$ for $\left.2 \mathrm{~min}\right)$ followed by 35 cycles of denaturation at $94^{\circ} \mathrm{C}$ for $30 \mathrm{~s}$, annealing at $50^{\circ} \mathrm{C}$ for $30 \mathrm{~s}$ and elongation at $72^{\circ} \mathrm{C}$ for $90 \mathrm{~s}$ and a final extension step of $72^{\circ} \mathrm{C}$ for $7 \mathrm{~min}$. Product purification and sequencing was performed by Macrogen Inc. sequencing service (Seoul, South Korea)using the same primers. Sequences were checked for errors and edited manually using the program BioEdit (HALL, 1999).

\section{Molecular species identification}

Two approaches for species identification were used, similarity analysis and phylogenetic inference. For all Tinodes DNA barcode sequences obtained in this study, simila- 
Tab. 1. Taxonomic designation, specimen ID, BOLD Sequence ID number, mitochondrial COI haplotype and geographic origin of the specimens used in analysis.

\begin{tabular}{|c|c|c|c|c|c|}
\hline No & Species name & Specimen ID & $\begin{array}{l}\text { BOLD Sequence ID } \\
\text { number }\end{array}$ & $\begin{array}{l}\text { mt COI } \\
\text { haplotype }\end{array}$ & Country \\
\hline & Tinodes antonioi & TTANT1 & NIP002-16 & \multirow{2}{*}{1} & Croatia \\
\hline & Tinodes sp. F & TTIN1 & NIP003-16 & & Croatia \\
\hline & Tinodes sp._M & TTIN2 & NIP004-16 & 2 & Croatia \\
\hline & Tinodes turanicus & 10HMCAD-021 & HMKKT021-10 & 3 & Kyrgyzstan \\
\hline & Tinodes n. sp. nr. turanicus & IQCAD135-09 & IQCAD135-09 & 4 & Iraq \\
\hline & Tinodes n. sp. nr. turanicus & IQCAD144-09 & IQCAD144-09 & \multirow{11}{*}{5} & \multirow{11}{*}{ Iraq } \\
\hline & Tinodes n. sp. nr. turanicus & IQCAD145-09 & IQCAD145-09 & & \\
\hline & Tinodes n. sp. nr. turanicus & IQCAD146-09 & IQCAD146-09 & & \\
\hline & Tinodes n. sp. nr. turanicus & IQCAD147-09 & IQCAD147-09 & & \\
\hline & Tinodes n. sp. nr. turanicus & IQCAD148-09 & IQCAD148-09 & & \\
\hline & Tinodes n. sp. nr. turanicus & IQCAD149-09 & IQCAD149-09 & & \\
\hline & Tinodes n. sp. nr. turanicus & 12IQTRA-0034 & TRIRA034-13 & & \\
\hline & Tinodes n. sp. nr. turanicus & 12IQTRA-0035 & TRIRA035-13 & & \\
\hline & Tinodes n. sp. nr. turanicus & 12IQTRA-0036 & TRIRA036-13 & & \\
\hline & Tinodes n. sp. nr. turanicus & 12IQTRA-0037 & TRIRA037-13 & & \\
\hline & Tinodes n. sp. nr. turanicus & 12IQTRA-0039 & TRIRA039-13 & & \\
\hline & Tinodes n. sp. nr. turanicus & 12IQTRA-0033 & TRIRA033-13 & 6 & Iraq \\
\hline & Tinodes n. sp. nr. turanicus & 12IQTRA-0038 & TRIRA038-13 & 7 & Iraq \\
\hline & Tinodes unicolor & 10HMCAD-493 & HMKKT493-10 & \multirow{3}{*}{8} & Austria \\
\hline & Tinodes unicolor & TFLAN218-11 & UA-SG-TRICH- D83 & & \multirow{2}{*}{ Belgium } \\
\hline & Tinodes unicolor & TFLAN219-11 & UA-SG-TRICH- D84 & & \\
\hline & Tinodes unicolor & TFLAN219-11 & BIOUG16521-D08 & 9 & Belgium \\
\hline & Tinodes waeneri & TTWAE1 & NIP001-16 & 10 & Croatia \\
\hline & Tinodes waeneri & TFLAN171-11 & UA-SG-TRICH-D86 & 11 & Belgium \\
\hline & Tinodes waeneri & 12HMCAD-62 & KJTRI057-13 & 12 & Austria \\
\hline & Tinodes waeneri & GBMIN40244-13 & FN179050 & 13 & Belgium \\
\hline & Tinodes braueri & TTBRA1 & NIP005-16 & 14 & Croatia \\
\hline & Tinodes pallidulus & TTPAL1 & NIP006-16 & 15 & Croatia \\
\hline & Tinodes pallidulus & 12HMCAD-068 & BHMKK235-12 & 16 & Austria \\
\hline & Tinodes rostocki & 12HMCAD-76 & KJTRI071-13 & 17 & Austria \\
\hline & Tinodes dives & TTDIV1 & NIP007-16 & 18 & Croatia \\
\hline & Tinodes dives consiglioi & 07HMCAD-0357 & HMCAD357-08 & 19 & Italy \\
\hline & Tinodes dives consiglioi & 07HMCAD-0359 & HMCAD359-08 & \multirow{2}{*}{20} & \multirow{2}{*}{ Italy } \\
\hline & Tinodes dives consiglioi & 07HMCAD-0361 & HMCAD361-08 & & \\
\hline & Tinodes dives consiglioi & 07HMCAD-0360 & HMCAD360-08 & 21 & Italy \\
\hline & Tinodes dives consiglioi & 07HMCAD-0358 & HMCAD358-08 & 22 & Italy \\
\hline & Tinodes higashiyamanus & AB764093 & GBMIN17824-13 & 23 & Japan \\
\hline & Tinodes provo & 08OFCAD-1186 & NECAD331-08 & 24 & United States \\
\hline & Tinodes provo & 08OFCAD-1187 & NECAD332-08 & 25 & United States \\
\hline & Tinodes provo & 08OFCAD-1188 & NECAD333-08 & 26 & United States \\
\hline & Psychomyia flavida & 07EVCAD-0528 & EVCAD528-07 & 27 & Canada \\
\hline & Psychomyia morisitai & AB764095 & GBMIN17823-13 & 28 & Japan \\
\hline & Lype diversa & 08DRCAD-049 & DRCAD049-08 & 29 & United States \\
\hline & Lype excisa & AB764091 & GBMIN17825-13 & 30 & Japan \\
\hline & Eoneureclipsis montanus & AB744044 & GBMIN21069-13 & 31 & Japan \\
\hline & Eoneureclipsis yaeyamaensis & AB764090 & GBMIN17793-13 & 32 & Japan \\
\hline & Eoneureclipsis okinawaensis & AB764089 & GBMIN17826-13 & 33 & Japan \\
\hline
\end{tabular}


rity search was performed using the BOLD Identification Engine (by April 2016) which uses all sequences uploaded to BOLD from public and private projects to locate the closest match.

Along with newly obtained Tinodes DNA barcodes, data set for phylogenetic analysis contained all available Tinodes DNA barcode sequences retrieved from the Barcode of Life Data Systems (BOLD; Ratnasingham \& Hebert, 2007) and GenBank (Benson et al., 2009) (Tab. 1) as well as sequences of Psychomyia flavida Hagen, Psychomyia morisitai Tsuda, Lype diversa (Banks), Lype excise Mey, Eoneureclipsis montanus Torii \& Nishimoto, Eoneureclipsis yaeyamaensis Torii \& Nishimoto, Eoneureclipsis okinawaensis Torii \& Nishimoto that were used as outgroups. Prior to analyses sequences were aligned using the program BioEdit (HALL, 1999) and collapsed into unique haplotypes using FaBox v.1.41 (Villesen, 2007). Phylogeny-based identification was conducted by using three different methods of tree reconstruction: Neighbor-Joining (NJ) and Maximum likelihood (ML) as implemented in MEGA 6.0. (TAMura et al., 2013) and Bayesian Inference (BI) in MrBayes 3.1.2 (Huelsenbeck \& Ronquist, 2001; Ronquist \& Huelsenbeck, 2003). For ML analysis and BI the best-fitting model of DNA substitution under Bayesian information criterion, General Time Reversible model (GTR+G+I), was selected using the jModelTest 0.1.1 (Posada, 2008). The Bayesian analysis (2 independent runs of four Markov chains) was conducted for 3,000,000 generations sampling every $100^{\text {th }}$ generation and discarding

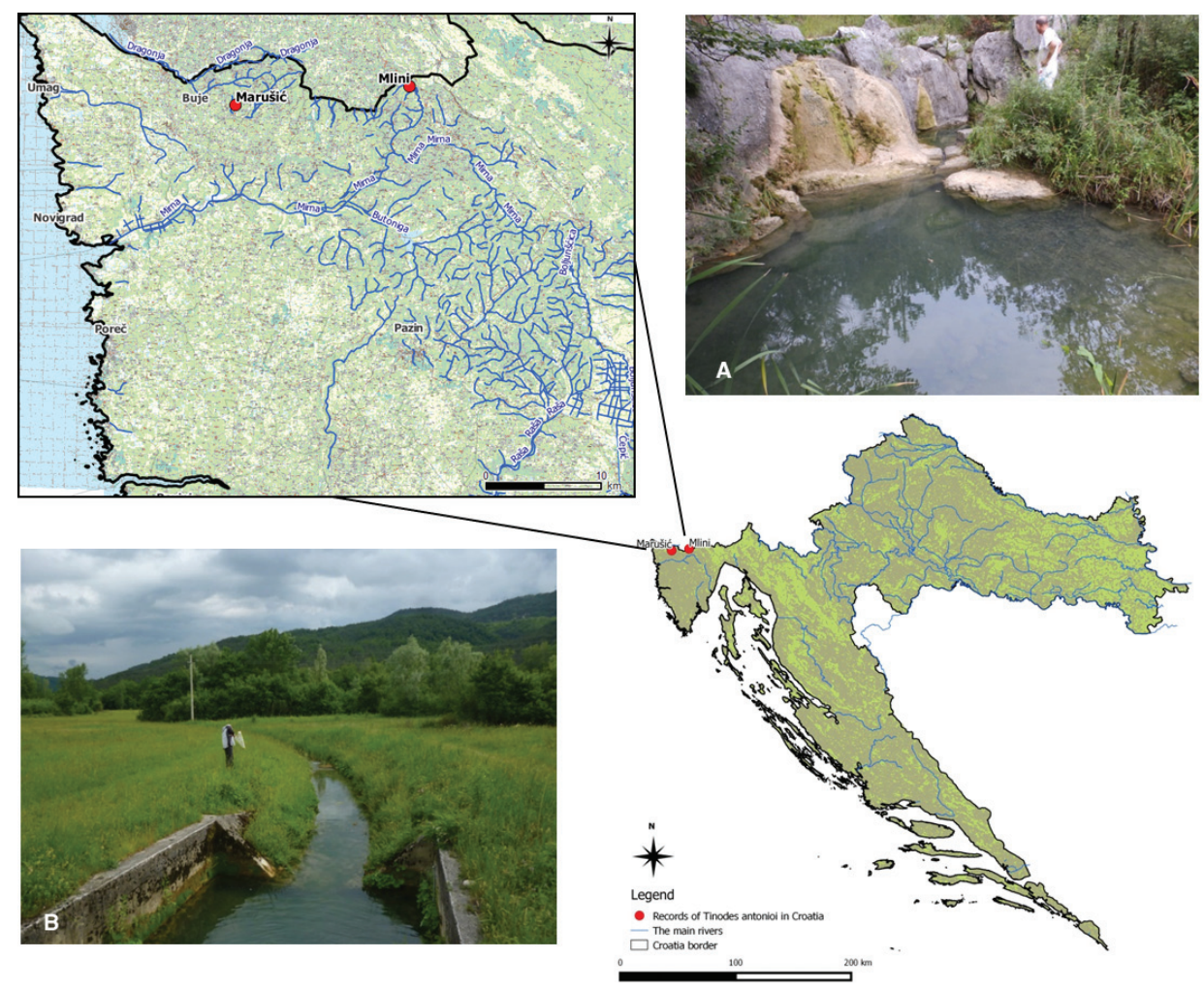

Fig. 1A-B. Map of Croatia with the study sites: a) Marušića Stream, b) Mlini Stream. 


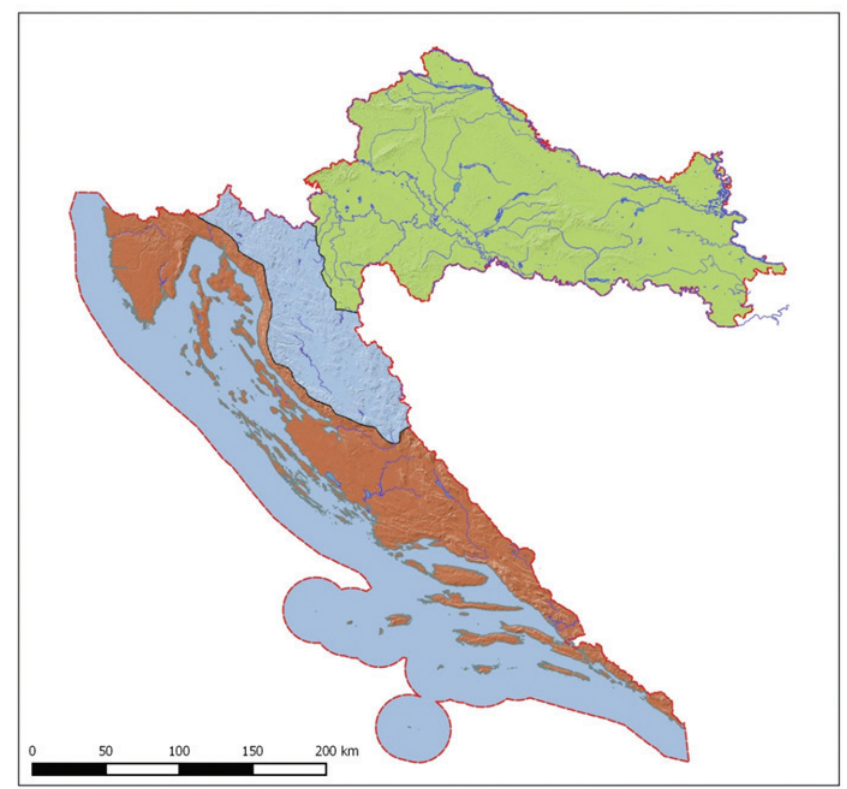

Fig. 2. Division of Croatia into: inland (Pannonian-peripannonian) (green colour), mountainous part (blue colour) and Mediterranean part (brown colour), according to Bertić et al. (2001).

the first $20 \%$ of trees as burn in. The nodal support for NJ and ML trees was assessed by 2000, and 1000 bootstrap replicates, respectively.

The uncorrected pairwise divergences between specimens ( $p$-distance) based on the mt COI barcode sequences were calculated in MEGA 6.0. (TAMura et al., 2013). Species delimitation method Automatic Barcode Gap Discovery, ABGD (Puillandre et al., 2012) based on the barcode gap (difference between inter- and intraspecific genetic distances) was applied to estimate the number of hypothetical species within data set. Data set (containing all Tinodes DNA barcode sequences as well as 2 Lype diversa mtDNA sequences) was submitted to the ABGD online website and analysed under following settings: $\mathrm{P}$ (prior intraspecific divergence) set from 0.001 (Pmin) to 0.08 (Pmax) and Steps set to $10 ; \mathrm{X}$ (minimum relative gap width) set to $1 ; \mathrm{Nb}$ bins (for distance distribution) set to 20; we selected the Kimura (K80) model and set TS/TV to 2.0.

\section{RESULTS AND DISCUSSION}

\section{Faunal data}

While the NIP project was being conducted in the area of the Marušića Stream and Mlini Stream, three species from the Tinodes genus were recorded: Tinodes antonioi (Figs.

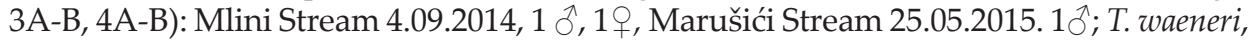

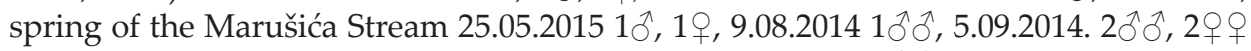
and T. pallidus: spring of the Marušića Stream 25.05.2015. 2ઈ̂. 1; T. antonioi never having been recorded in the fauna of Croatia previously. The species was described by Botosaneanu and Taticchi-Viganò from specimens collected in Italy (BotosANEANU \& 
Taticchi-Viganò, 1974). The female of the species was later described in a paper of CIANFICCONI et al. (1994), also from specimens taken in Italy. T. antonioi has rather small dimensions, and from the data in the literature, the span of the anterior wings is $8 \mathrm{~mm}$ (MALICKY, 2004). In the Atlas of European Trichoptera (MaLicky, 2004) the morphological features of the genitalia of females from the genus Tinodes have been presented for only 10 species, for in most species they are extremely similar and the females of the different species cannot be distinguished from each other by their morphological characteristics. This is not the case with the genitalia of the females of the species Tinodes antonioi, for they are very specific and easily identifiable (CiAnficConi et al., 1999) so that unlike many other species of the genus Tinodes the find of a female is sufficient for certain establishment of the presence of this species in a given area.

In Europe, T. antonioi has been recorded in France, Italy, Switzerland, Slovenia (CIANFicCONi, 2002; KRUŠnik \& URbanič, 2002; BotosaneANU \& GiUdicelli, 2004) (Fig. 5) and now in Croatia. The greatest number of finds of this species have been made in Italy, and finds in Croatia are peripheral in one part of its south-east distribution area. Apart from the species T. antonioi, two other species of Tinodes have been recorded in Istria: T. pallidulus and T. waeneri.
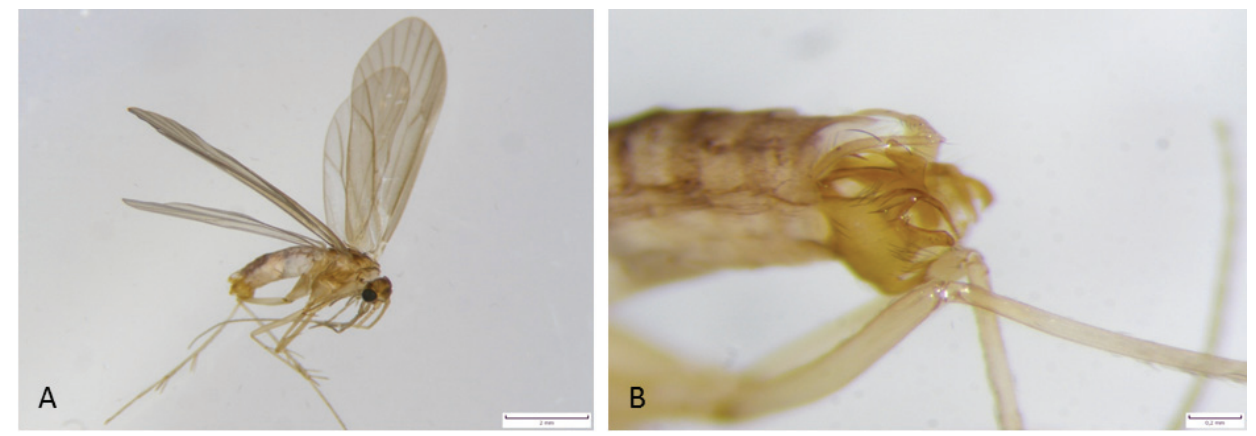

Fig. 3. A-B. Adult (A) and morphological features of male genitalia (B - lateral view) of the species Tinodes antonioi.
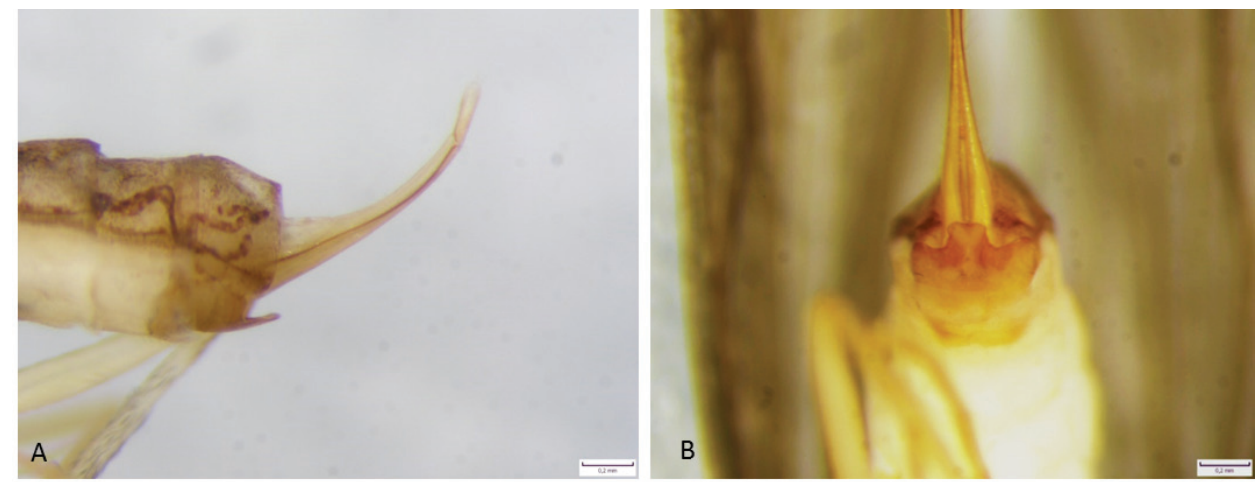

Fig. 4. A-B. Morphological feature of female genitalia of the species Tinodes antonioi: A - lateral view, B - ventral view. 


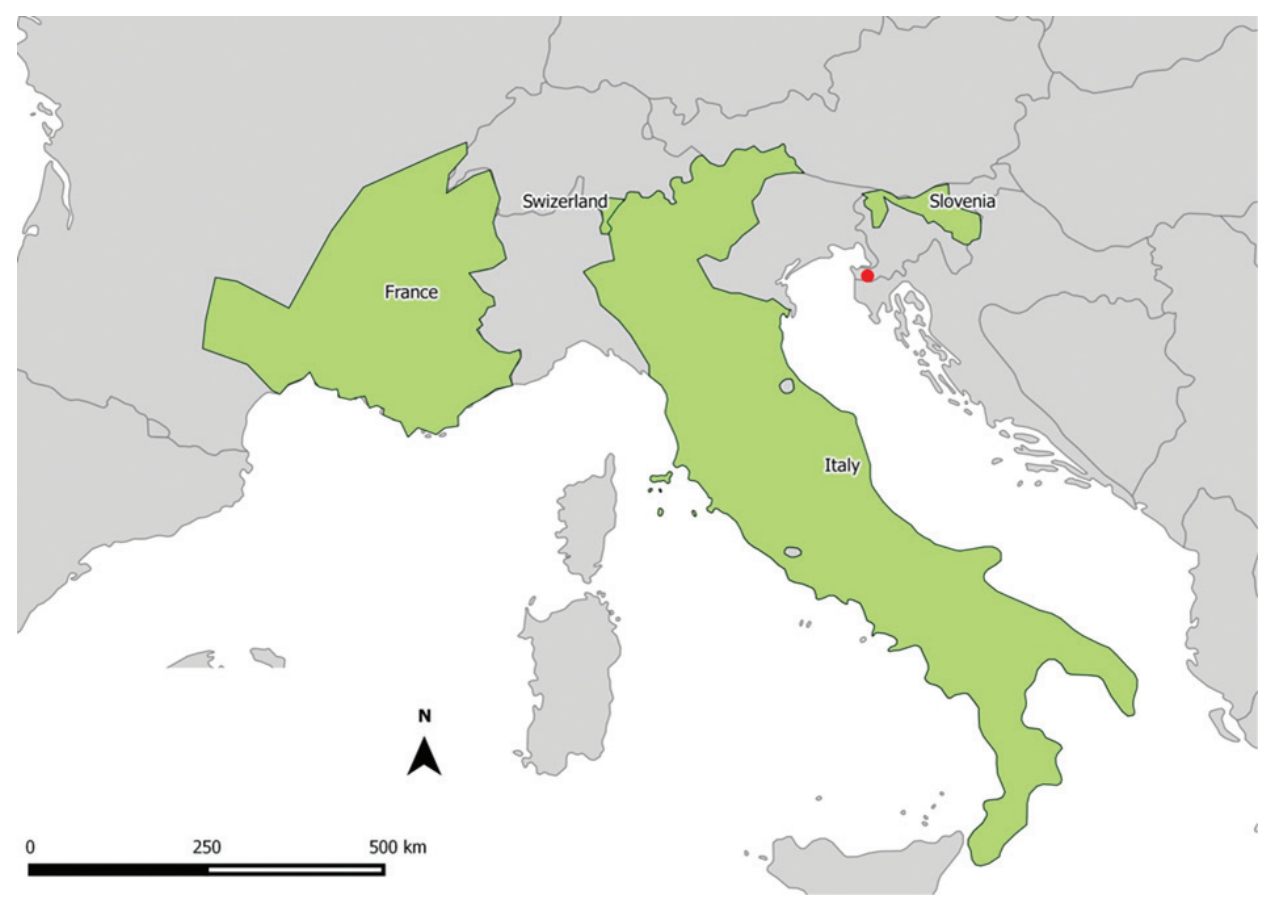

Fig. 5. Distribution of Tinodes antonioi in Europe (green field), compiled from Robert (2015) available at online www.freshwaterecology.info and MALICKY (2013) available at web portal Fauna Europaea with new findings in Croatia (red point).

\section{Genetic identification of Tinodes species and phylogenetic analysis}

BOLD Identification Engine failed to identify Tinodes antonioi (TTANT1) and Tinodes sp. specimens (female TTIN1 and male TTIN2 having slightly different morphology) to species level since DNA barcode of this species has not yet been submitted to BOLD. That is why the molecular identification of Tinodes sp. could be carried out only on the basis of comparison of DNA sequences of those samples with the DNA sequence of a sample undoubtedly morphologically identified as T. antonioi (TTANT1) and also DNA sequences of all known species of genus Tinodes occuring in Croatia except T. andrasi. The male T. antonioi (TTANT1) and female Tinodes sp. (TTIN1) have identical COI haplotype, and haplotypes of Tinodes sp. male (TTIN2) and T. antonioi (TTANT1) differ by a single base substitution. In phylogenetic trees derived by all three methods (Neighbor-Joining, Maximum-Likelihood and Bayesian Inference) those three samples cluster within highly supported monophyletic clade (support 100/100/1, Fig. 6) proving Tinodes sp. belonging to species T. antonioi. T. antonioi is clearly separated from all other Tinodes species recorded in Croatia (Fig. 6).

The $p$-distances of the 658-bp-long fragment of the $\mathrm{mt}$ COI gene (barcoding region) between different Tinodes species range from $10 \%$ to $27 \%$, while the obtained intraspecific $p$-distances are in range of $0-3 \%$ (Tab. 2). The lowest interspecific distance values are recorded between T. antonioi and T. n. sp. nr. turanicus (10\%) and higest between T. antonioi and T. higashiyamanus (24\%) (Tab. 2). 


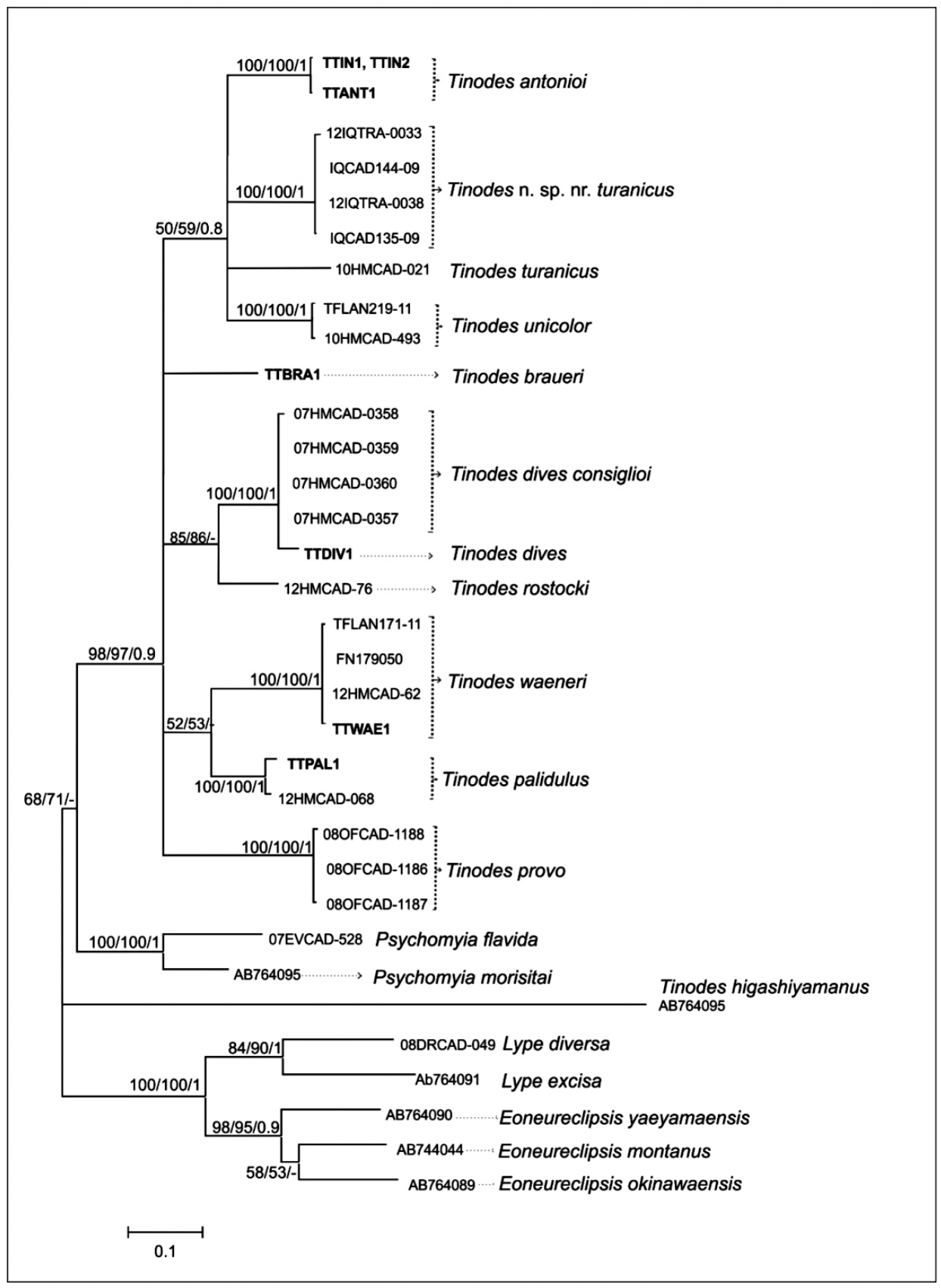

Fig. 6. Maximum likelihood phylogram based on $658 \mathrm{bp}$ long fragment of the DNA barcode region showing the relationships between Tinodes species from this study and different species from family Psyiichomidae. Numbers above the branches represent bootstrap support (BS) and Bayesian posterior probabilities (BPP) in order NJ/ML/BA. BS values less than 50 and BPP values less than 90 are not shown. Specimen ID from sequences obtained in this study (from Croatia) are written with bold letters. 


\begin{tabular}{|c|c|c|c|c|c|c|c|c|c|c|c|c|c|}
\hline Psychomyia flavida & & & & & & & & & & & & & 0 \\
\hline T. provo & & & & & & & & & & & & 0 & $\begin{array}{l}\text { ma } \\
\stackrel{1}{1} \\
\stackrel{1}{0} \\
-1\end{array}$ \\
\hline T. higashiyamanus & & & & & & & & & & & 0 & 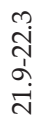 & $\stackrel{\infty}{\stackrel{\infty}{\sim}}$ \\
\hline T. dives consiglioi & & & & & & & & & & $\begin{array}{l}\text { Ln } \\
\stackrel{1}{0} \\
\stackrel{0}{0}\end{array}$ & ث̊. & $\begin{array}{l}a \\
\text { î } \\
\hat{b} \\
\text { d. }\end{array}$ & $\vec{\sigma}$ \\
\hline T. dives & & & & & & & & & ○ & 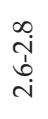 & @̊̀ & $\frac{m}{\stackrel{m}{m}}$ & $\stackrel{\infty}{\stackrel{\infty}{\leftrightarrow}}$ \\
\hline T. rostocki & & & & & & & & 0 & $\sigma$ & $\begin{array}{l}\vec{a} \\
\stackrel{1}{\Lambda} \\
\infty\end{array}$ & 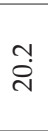 & 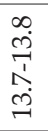 & $\stackrel{\infty}{\stackrel{\infty}{-}}$ \\
\hline T. pallidulus & & & & & & & $\begin{array}{l}1 \\
0 \\
\vdots \\
0\end{array}$ & $\begin{array}{l}\text { ले } \\
\stackrel{0}{\circ}\end{array}$ & \begin{tabular}{l}
0 \\
$\stackrel{0}{0}$ \\
\multirow{1}{1}{} \\
$\stackrel{0}{0}$ \\
0
\end{tabular} & 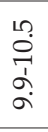 & $\begin{array}{l}\text { N̦ } \\
\text { ஸे } \\
\infty \\
\infty \\
\sigma\end{array}$ & 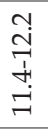 & 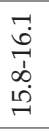 \\
\hline T. braueri & & & & & & 0 & 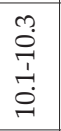 & $\stackrel{1}{\stackrel{0}{0}}$ & 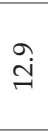 & 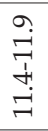 & $\stackrel{\vec{\sim}}{\vec{\sim}}$ & 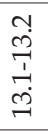 & $\begin{array}{l}\stackrel{10}{0} \\
\stackrel{10}{n}\end{array}$ \\
\hline T. waeneri & & & & & 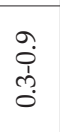 & 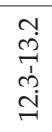 & 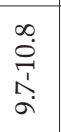 & $\begin{array}{l}\stackrel{a}{1} \\
\text { İ } \\
\stackrel{\sim}{\sim}\end{array}$ & 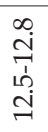 & 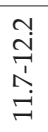 & 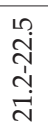 & 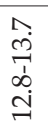 & 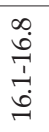 \\
\hline T. unicolor & & & & $\stackrel{m}{0}$ & 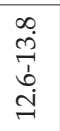 & $\begin{array}{l}\stackrel{M}{\mathrm{I}} \\
\underset{\mathrm{J}}{\mathrm{J}}\end{array}$ & $\begin{array}{l}\stackrel{\triangle}{ت} \\
\stackrel{I}{ت} \\
ت\end{array}$ & 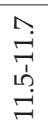 & $\begin{array}{l}\stackrel{I}{+} \\
\stackrel{+}{+} \\
\dot{+}\end{array}$ & 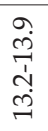 & 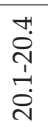 & 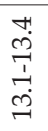 & $\begin{array}{l}m \\
\infty \\
\infty \\
\stackrel{1}{1} \\
\infty \\
=\end{array}$ \\
\hline Ti-n. sp. nr. turanicus & & & $\stackrel{\vec{I}}{\stackrel{5}{0}}$ & 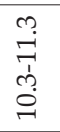 & 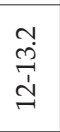 & 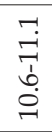 & 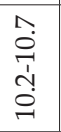 & 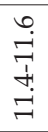 & 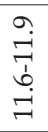 & 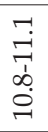 & 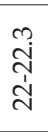 & \begin{tabular}{l} 
ָ̃ \\
\multirow{1}{b}{} \\
$\stackrel{\Xi}{\sigma}$
\end{tabular} & $\begin{array}{l}\hat{\sigma} \\
\sigma \\
b \\
b \\
\sigma\end{array}$ \\
\hline T. turanicus & & 0 & $\begin{array}{l}\text { aे } \\
\hat{a} \\
\stackrel{\sigma}{0}\end{array}$ & 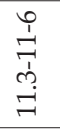 & 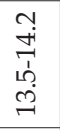 & $\stackrel{\text { I }}{ }$ & 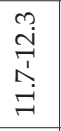 & $\stackrel{\not}{ت}$ & $\stackrel{\oplus}{\vec{\omega}}$ & 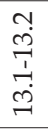 & 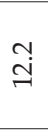 & 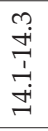 & $\stackrel{+}{\stackrel{H}{2}}$ \\
\hline T. antonioi & $\begin{array}{l}\breve{1} \\
\vdots \\
0\end{array}$ & $\stackrel{\leftrightarrow}{\circ}$ & $\begin{array}{l}m \\
\stackrel{n}{\circ} \\
\stackrel{1}{\circ} \\
\sigma\end{array}$ & $\underset{\exists}{\rightrightarrows}$ & $\begin{array}{l}\infty \\
\dot{m} \\
\dot{I} \\
\stackrel{m}{\sim}\end{array}$ & $\stackrel{1}{\stackrel{0}{0}}$ & 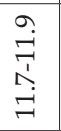 & $\begin{array}{l}\stackrel{n}{\sim} \\
\stackrel{\sim}{\sim}\end{array}$ & $\stackrel{\leftrightarrow}{\oplus}$ & 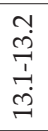 & 犬্ं & 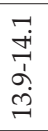 & $\stackrel{\sim}{\infty}$ \\
\hline $\bar{\theta}$ & 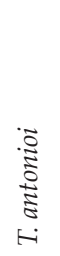 & 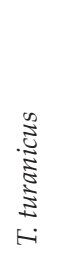 & 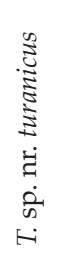 & 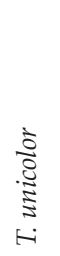 & 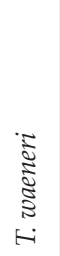 & 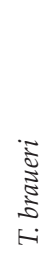 & 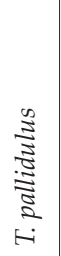 & 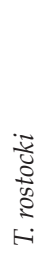 & 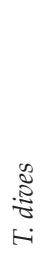 & 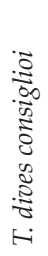 & 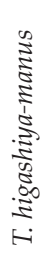 & $\begin{array}{c}\stackrel{2}{2} \\
\stackrel{2}{2} \\
\text { Hid }\end{array}$ & 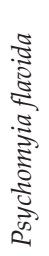 \\
\hline
\end{tabular}


The ABGD analysis clustered the sequences into 13 groups. T. antonioi formed one group separated from other Tinodes. Each of Tinodes species and outgrups clustered according to systematic (Fig. 7). The ABGD method shows intra- and interspecific distance variation, the barcoding gap between species and genus (Fig. 8).

Although direct molecular level conformation of morphological identification of specimens from Istria as T. antonioi could not been made, molecular analysis proved that those specimens do not belong to any other Tinodes species currently recorded in Croatia. The only exception is T. andrasi whose DNA barcodes was not available in this study. However, since this species is endem of Konavle region (south Croatia) it is hard to belive that Istrian specimens identified as T. antonioi in this study could be missidentified with this southern species.

The phenotype differences between Croatian population of T. antonioi, are not reflected on the molecular (mtCOI) level. Comparison of DNA barcode sequences of morphologically different $T$. antonioi proved once again that morphological differences in caddisflies do not necessarily indicate new taxa and that inclusion of some genetic marker in the analysis have to be considered. As in many previous studies (e.g. PAuls et al., 2010; JACKson et al., 2014; ZHou et al., 2007; ZHou, 2009) also in this study, DNA barcoding proves as fast and reliable method for resolving morphological doubts.

The clear DNA barcode gap exists within Tinodes. The minimum value of uncorrected pairwise sequence divergences ( $p$-distances) for DNA barcode region between Tinodes species analysed in this study $(9 \%)$ is higher than minimum values of the interspecific variability usually observed in caddisflies for the mtCOI barcode region (8\% PAuls et al., 2010; 5.3\% ZHou, 2009; 8.2\% GrAF et al., 2015). The maximum observed intraspecific divergence value was $3 \%$. The unusually high maximum intraspecific divergence $(3 \%)$ is recorded between $T$. dives from Croatia and subspecies $T$. dives consiglioi from Italy indicating the existence of deeply separated evolutionary lineages within species. It is interesting that lowest interspecific divergence values for DNA barcode region was found between geographically distant species T. antonioi from Croatia and T. n. sp. nr. turanicus from Iraq, however the sister relation between them was not supported in phylogenetic analyses. Detailed phylogenetic analysis of the genus Tinodes would require the implementation of additional mitochondrial and nuclear markers. At the moment, obtained DNA barcodes of rare Croatian Tinodes species represent valuable contribution to global DNA barcoding effort. In most papers this Alpino-Apenninic endemic, T. antonioi, is presented with few specimens. According to Cianficconi \& Corallini (2010), 1 male, 1 female in Molise, Italy; according to Botosaneanu \& Giudicelli (2004) in France on each of four locations they collected one male and on only one location one female; during six years of research on 38 sampling sites on the River Chiascio in Umbria, Italy according to CIANFICCONI et al., 1999 most specimens are present with one or two female and only one time there were 11 specimens.

\section{Ecological data}

The ecological and ethological characteristics of T. antonioi are not known in detail, although they do fit within some of the properties of the genus itself. We recorded the species T. antonioi only in the upper reaches of the two streams, the Milni and the Marušića, and did not record it in any larger watercourses (the River Raša) or in the Butoniga Reservoir in Istria during this research. The find of T. antonioi in the Milni Stream is interesting; it was collected only at a site located downstream from the spring, one that is subject to considerable anthropogenic influence, which means that this species 


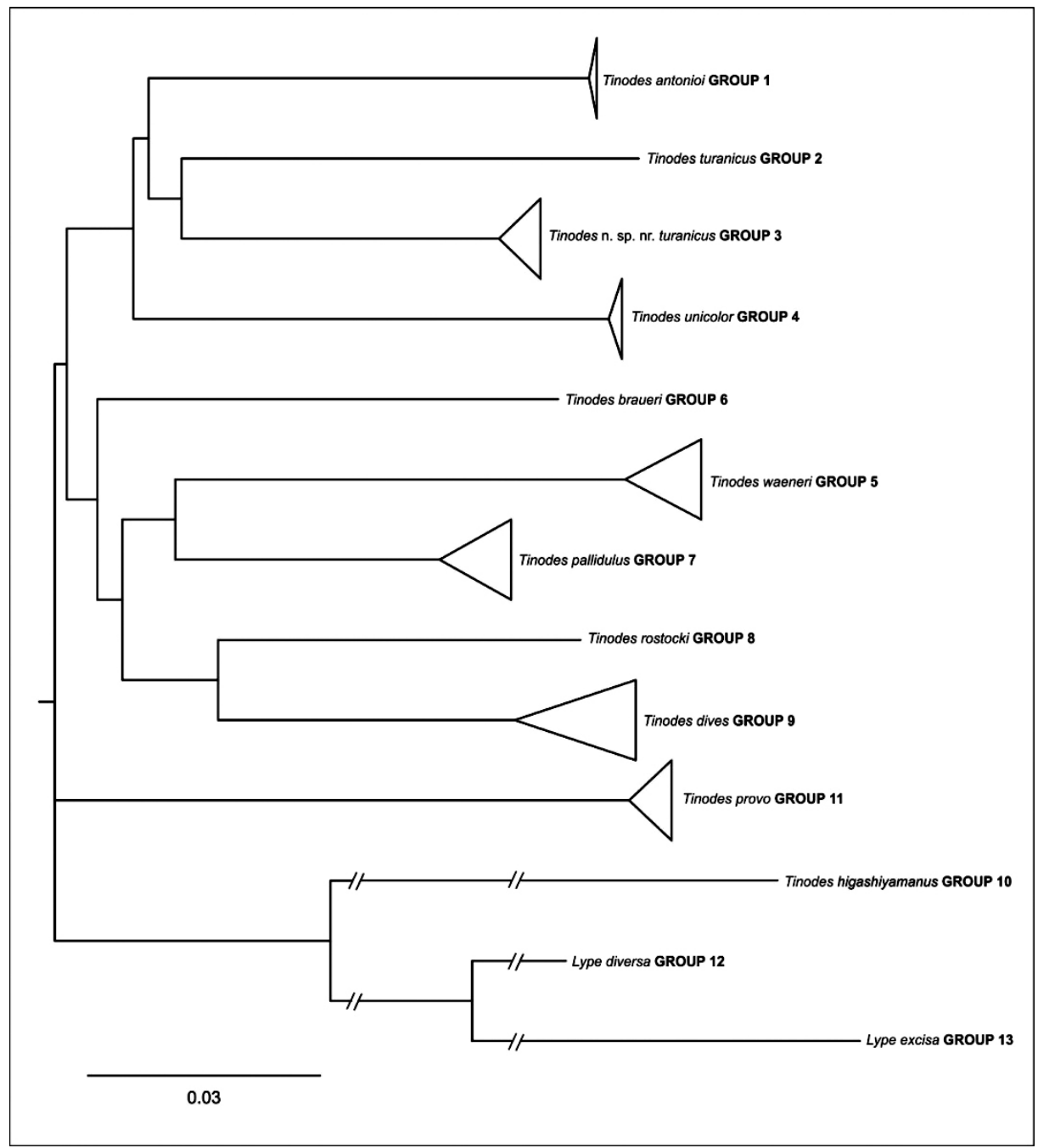

Fig. 7. Neighbor-Joining phylogenetic tree showing groups (hypothetical species) as revealed by Automatic Barcode Gap Discovery (ABGD) analysis.

may appear at this kind of habitat. We have to point out however that it seems to us the water in the Mlini at this site is of good quality (without either organic or inorganic pollution) but there has been considerable anthropogenic impact on the hydrological characteristics of the stream in his part (Fig. 1B).

This research determined adult emergence of T. antonioi to be in May and and September. Since collections were not made in all the spring, summer and autumn months, an earlier as well as a later emergence than the months given is also possible. Details in the literature indicate findings of T. antonioi in a fairly long period from May to September (Botosaneanu \& Giudicelli, 2004). The strongest emergence period was recorded for Italy in August by Cianficconi et al. (1999). According to Botosaneanu \& Giudicelli 


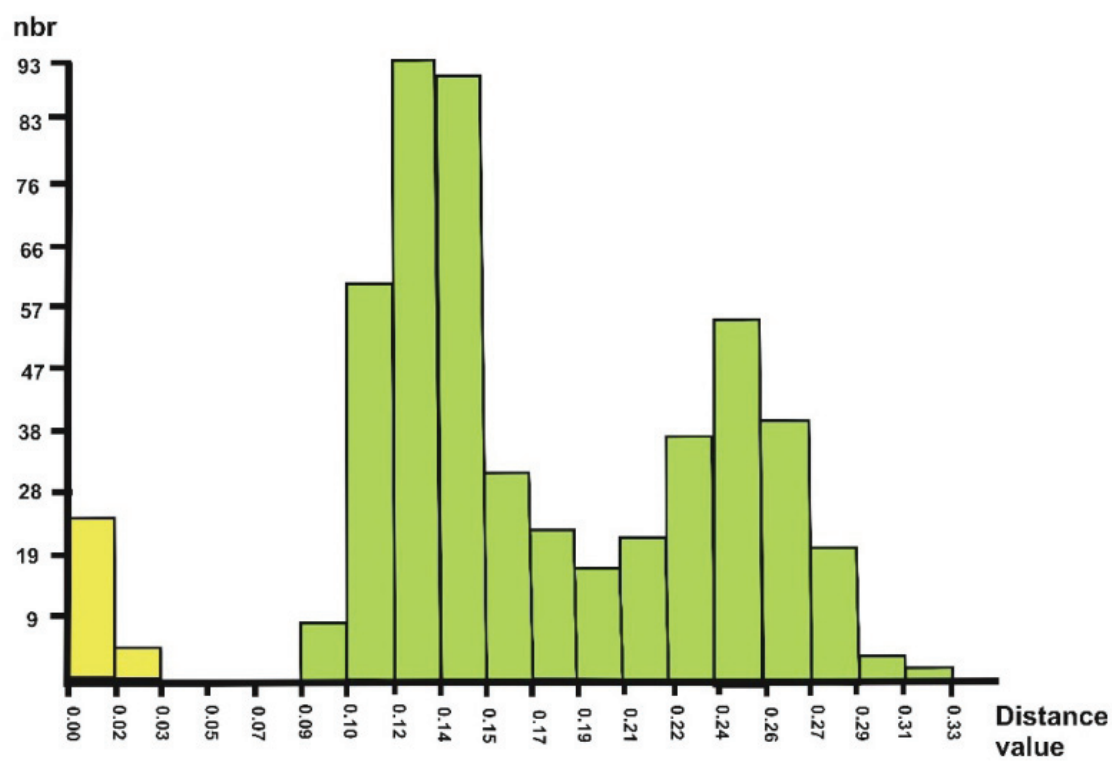

Fig. 8. Histogram depicting the frequency distribution of K2P distances within Tinodes as revealed by ABGD analysis. The horizontal axis shows the pairwise K2P-distance, and the vertical axis shows the number of pairwise sequence comparisons. On the left side of histogram (yellow colour) is intraspecific and on right is interspecific (green colour) distance variation.

(2004), T. antonioi comes in France from 120 to $1070 \mathrm{~m}$ above sea level, and research in Italy has found it at above sea level heights of from 360 to $870 \mathrm{~m}$ (CIANFICCONi et al., 1999).

All the adults were collected at night, in UV lamp-assisted catching, and thus in this research we recorded no diurnal T. antonioi activity.

During caddisfly research in Croatia that has in the last 20 years included the collection of adults at more than 240 sites, T. antonioi has been recorded only in this research, which suggests that apart from Istria it probably does not come to any other region in Croatia. Because there are only these two finding sites in Croatia as of present, in order to preserve this species in the country's fauna, the site at the Marušića Stream, as well as the stream itself, particularly the upper part, should be protected against any anthropogenic impacts, and any such impact on Mlini Stream should be reduced to the minimum level possible.

\section{Biodiversity of the genus Tinodes in Croatia, with a note on its distribution}

The genus Tinodes is one of the most numerous in the fauna of Europe, with some one hundred or so species recorded (MALICKY, 2004). In the fauna of Croatia, eight species of this genus have been recorded (e.g., Graf et al., 2008; Kučinić, 2002; OláH, 2010; Cerjanec, 2012, M. Kučinić unpublished data): Tinodes andrasi Oláh,, T. antonioi Botosaneanui \& Tattichi-Viganò, T. braueri McLachlan, T. dives Pictet, T. pallidus McLachlan, T. rostocki McLachlan, T. unicolor Pictet and T. waeneri Linnaeus. Larva of Tinodes braueri was described from specimens collected in the Rive Cetina in Croatia (Graf et al., 2008). 
Every one of these species has its own particular features with respect to morphology genetics, ecology and distribution and, when the fauna of Croatia is at issue, particularly remarkable for specificity is the species Tinodes andrasi, which has to date been found only in Croatia. This species was described a few years back on the basis of just a single example of a male found in the area of the Ljuta River (locus typicus) in Konavle (Dalmatia) (OLÁH, 2010).This is to date the only find of this species and still to be attempted is a more detailed investigation of its distribution in Konavle and wider and the find of a female, no collection of which has yet been made, in order to ascertain potential morphological particularities. When the NIP project was conducted in the Konavle region, the collection of caddisflies took place at four sites during 2014. At these sites, the species T. andrasi was not ascertained.

Tinodes andrasi, according to the author of the description (OLÁH, 2010) is very similar to the species T. rostocki, which has also been recorded in Croatia (north), as well as more to the south, in Albania and Greece (Malicky, 2005; OláH \& Kovács, 2014). Since the morphological differences of the male genitalia in the species T. rostocki and T. andrasi are not very great (which is the case with a certain number of other species of caddisfly, (Malicky, 2004, 2014; OlÁH, 2010; Previšić et al., 2014a) and the ranges of T. andrasi and T. rostock $i$ are in a sense overlapping, additional molecular research into these two species is required for the sake of determining their exact taxonomic and phylogenetic relations. It can be assumed from their distributions and the similarity of the male genitalia that they have great phylogenetic affinity.

Similarly, a very nice example of speciation and the relations of two phylogenetically closely related species, one of which has a very large and the other a very small range, can be found in the genus Ecclisopteryx, in which the species E. keroveci has a large range, extending from the spring of the Čabranka to Macedonia (Previšić et al., 2014a; OláH \& Kovács, 2014), while the endemic species E. ivkae (Previšić et al., 2014a) makes a distinctly separate enclave in the central part of the area in the source areas of the Cetina River. The species E. keroveci and E. ivkae are fairly, or very, similar in their morphologies, although by careful analysis of the genitalia it is possible to distinguish both males and females, they are genetically different, but not in a high degree and have considerable differences in the morphology of the larvae (Previšić et al., 2014a). All these features are

Tab. 3. Distribution of species of the genus Tinodes in inland, central-mountain and Mediterranean parts of Croatia.

\begin{tabular}{|l|c|c|c|}
\hline Species & $\begin{array}{c}\text { Inland part of } \\
\text { Croatia }\end{array}$ & $\begin{array}{c}\text { Mountainous part of } \\
\text { Croatia }\end{array}$ & $\begin{array}{c}\text { Mediterranean part } \\
\text { of Croatia }\end{array}$ \\
\hline Tinodes andrasi & - & - & + \\
\hline Tinodes antonioi & - & - & + \\
\hline Tinodes braueri & - & + & + \\
\hline Tinodes dives & + & + & + \\
\hline Tinodes pallidus & + & + & - \\
\hline Tinodes rostocki & + & + & + \\
\hline Tinodes unicolor & + & + & 6 \\
\hline Tinodes waeneri & - & 5 & + \\
\hline TOTAL & 4 & & + \\
\hline
\end{tabular}


enough for the population in the upper course of the Cetina to be defined as specific at the level of a separate species, which has been described as such (Previšić et al., 2014a).

In research to date in the Mediterranean region of Croatia, 6 species of the genus Tinodes have been recorded, with five in the upland or mountain region and four species in the inland or continental region (Tab. 3).

\section{ACKNOWLEDGMENTS}

We are very grateful to two anonymous referees for their useful suggestions and also to Graham McMaster for his assistance with the English language. This study was supported by the "EU Natura 2000 Integration Project (NIP)" funded by the Croatian Ministry of Environmental and Nature Protection.

Received May 15, 2016

\section{REFERENCES}

Benson, D.A., Karsch-Mizrachi, I., Lipman, D.J., Ostell, J. \& Sayers, E.W., 2009: GenBank. Nucleic Acids Research 26-31. 10.1093/nar/gkn723. 37 Database

Bertić, I., LAmpek PAvČnik, I. \& Radovinović, R. (eds), 2001: Satelitski atlas Hrvatske. Naklada Ljevak i Gisdata, pp. 360, Zagreb.

Botosaneanu, L. \& Taticchi-Viganò, M., 1974: Description d'une nouvelle espèce du genre Tinodes (Trichoptera, Psychomyiidae). Boll. Mus. Zool. Univ. Torino, 2, 9-14.

Botosaneanu, L. \& Giudicelli, J., 2004: Contributions to the knowledge of the fauna of Caddisflies (Insecta: Trichoptera) from southeast France, with description of new taxa. Annales de Limnologie - International Journal of Limnology 40 (1), 15-32.

CERJANEc, D., 2012: Ecological and biogeographical features of caddisflies (Insecta: Trichoptera) in different types of habitats in drainage of the Dobra River. PhD-Thesis (in Croatian), University of Zagreb, pp 226, Zagreb.

Cianficconi, F., 2002: The third list of Italian Trichoptera (1990-2000). Proceedings of the 10th International Symposium on Trichoptera (Ed. W. Mey). Nova Supplementa Entomologica 15, 349-358.

Cianficconi, F., Mazzerioli, S., Moretti, G.P. \& Salerno P., 1999: La tricotterofauna di due sistemi tributari del F. Chiascio (Umbria). Bollettino della Società Entomologica Italiana 131(2), 147-177.

Cianficconi, F. \& Corallini, C., 2010: Trichopteran fauna in a region of Central-Southern Italy: Molise. Denisia 29, 81-104. La Tricotterofauna di sue tributari del F.Chiascio (Umbria)

Ćuk, R. \& VučKović, I., 2014: The first record of caddisfly Setodes viridis (Fourcroy, 1785) (Insecta: Trichoptera) in Croatia. Natura Croatica 23 (2), 407-413.

Folmer, O., Black, M., Hoeh, W., Lutz, R. \& Vrijenhoek, R., 1994: DNA primers for amplification of mitochondrial cytochrome c oxidase subunit I from diverse metazoan invertebrates. Molecular marine biology and biotechnology 3, 294-299.

Gíslason, G. M., Hannesdóttir, E. R., Munoz, S. S. \& Pálsson, S., 2015: Origin and dispersal of Potamophylax cingulatus (Trichoptera: Limnephilidae) in Iceland. Freshw Biol 60, 387-394. doi:10.1111/ fwb.12501.

Graf, W., Kučinić, M., Previšić, A, Vučković, I. \& Waringer, J., 2008: The Larva, ecology and distribution of Tinodes braueri McLachlan, 1878 (Trichoptera: Psychomyiidae). Aquatic insects 30 (4), $295-299$.

Graf, W., Vitecek, S., Previšić, A. \& Malicky, H., 2015: New species of Limnephilidae (Insecta: Trichoptera) from Europe: Alps and Pyrenees as harbours of unknown biodiversity. Zootaxa 3911 (3), 381-395. http://dx.doi.org/10.11646/zootaxa.3911.3.5

HabdijA, I., 1979: Ličinke Trichoptera kao indikatori ekologijskih prilika u bentosu krških voda. In: RAUš (ed.), Drugi kongres ekologa Jugoslavije (Second Congress of Ecologists of Yugoslavia). Savez društava ekologa Jugoslavije, Zagreb, pp. 1433-1446.

HabdijA, I., 1989: Trophic importance of trichopterous larvae in benthos oft he lakes Plitvice. Periodicum Biologorum 90 (3), 355-361. 
Habdija, I., Primc-Habdija, B., MatoničKin, R., Kučinić, M., Radanović, I., Miliša, M. \& Mihaljević, Z., 2003: Current velocity and food supply as factors affecting the composition of macroinvertebrate communites in bryophyte habitats on a calcareous tufa barrige in karst running water. Biologija 59 (5), 577-593.

HALl, T.A., 1999: BioEdit: A user-friendly biological sequence alignment editor and analysis program for Windows 95/98/NT. Nucl Acids Symp Ser., 41, 95-98

Hebert, P.D.N., CYwinska, A., BALL S.L. \& DeWAard J.R., 2003a: Biological identifications through DNA barcodes. Proceedings of the Royal Society of London, Series B 270, 313-322.

Hebert, P.D.N., Ratnasingham, S. \& DeWAard, J.R., 2003b: Barcoding animal life: Cytochrome c oxidase subunit 1 divergences among closely related species. Proc R Soc Lond B Biol Sci 270, S596-S599.

HuELSENBECK, J.P. \& RonQuist F., 2001: MrBayes: Bayesian inference of phylogenetic trees. Bioinformatics 17, 754-755. 10.1093/bioinformatics/17.8.754.

Ibrahimi, H., KuČinić, M., Gashi, A. \& Grapci-Kotori, L., 2012: The caddisfly fauna (Insecta, Trichoptera) of the rivers of the Black Sea basin in Kosovo with distributional data for some rare species. Zookeys $182,71-85$.

Ibrahimi, H., Kučinić, M., Gashi, A. \& Grapci-Kotori, L., 2014: Trichoptera Biodiversity of the Aegan and Adriatic Sea basin in the Republic of Kosovo. Journal of Insects Science, 14, 1-8.

Ibrahimi, H., Kučinić, M., Vitecek, S., Waringer, J., Graf, W., Previšić, A., Bálint, M., Kereszztes, L. \& Pauls, S.U., 2015: New records for the Kosovo caddisfly fauna with the descriptionof a new species, Drusus dardanicus sp. nov. (Trichoptera: Limnephilidae). Zootaxa 4032 (5), 551-568.

Ibrahimi, H., Vitecek, S., Previšić, A., Kučinić, M., Waringer, J., Graf, W., Balint, M., Kereszztes, L. \& PAuls, S.U., 2016: Drusus sharrensis sp. n. (Trichoptera, Limnephilidae), a new species from Sharr National Park in Kosovo, with molecular and ecological notes. ZooKeys 559, 107-124. doi: 10.3897/ zookeys.559.6350

Jackson, J. K., J. M. Battle, B. P. White, E. M. Pilgrim, E. D. Stein, P. E. Miller, \& B. W. Sweeney, 2014: Cryptic biodiversity in streams: a comparison of macroinvertebrate communities based on morphological and DNA barcode identifications. Freshwater Science 33, 312-324.

Jinbo, U., Kato, T. \& Iто, M., 2011: Current progress in DNA barcoding and future implications for entomology. Entomological Science 14, 107-124.

KRUŠnik, C. \& Urbanič, G., 2002: Preliminary List of Slovenian Trichoptera.Proceedings of the 10th International Symposium on Trichoptera (Ed. W. MeY). Nova Supplementa Entomologica 15, 359-364.

KučINIĆ, M., 2002: Raznolikost i rasprostranjenost tulara (Trichoptera, Insecta) u staništima Plitvičkih jezera. Doktorska dizertacija, Sveučilište u Zagrebu, 138pp, Zagreb (in Croatian).

KučinIĆ, M. \& MALICKY, H., 2002: Rhyacophila dorsalis plitvicensis new subspecies from Croatia. Proceedings of the 10th International Symposium on Trichoptera (Ed. W. MEY). Nova Supplementa Entomologica 15, 145-147.

Kučinić, M., Previšić, A., Gottstein, S., Hrašovec, B., Stanić-Koštroman, S., Pernek, M. \& Delić, A., 2008: Description of the larvae of Drusus radovanovici septentrionis Marinković-Gospodnetić, 1976 and Drusus croaticus Marinković-Gospodnetić, 1971 (Trichoptera: Limnephilidae) from Bosnia and Herzegovina, and Croatia. Zootaxa 1783, 1-17

Kučinić, M., VučKović, I., KutnjaK, H., Šerić Jelaska, L. \& Marguš, D., 2011a: Diversity, distribution, ecology and biogeography of caddisflies (Insecta: Trichoptera) in the Krka River (National Park „Krka”, Croatia). Zoosymposia 5, 255-268.

Kučinić, M., Previšić, A., Graf, W., Šerić Jelaska, L., Stanić-Koštroman, S. \& Waringer, J., 2011b: Larval description, genetic and ecological features of Drusus radovanovici radovanovici MarinkovićGospodnetić, 1971 (Trichoptera: Limnephilidae: Drusinae) with some phylogenetic and taxonomic data on the bosnicus group in the Balkan Peninsula. Deutsche Entomologische Zeitschrift 58 (1), 135-153.

Kučinić, M., Szivák, I., Pauls, S.U., Bálint, M., Delić, A. \& VučKović, I., 2013: Chaetopteryx bucari sp. n. a new species from the Chaetopteryx rugulosa group from Croatia (Insecta, Trichoptera) with some molecular, taxonomical and ecological notes on the group. Zookeys 320, 1-28.

Kučinić, M., Delić, A., ĆuK, R., Previšić, A., Minoci, I., ŽGanec, K., Cerjanec, D. \& VučKović, I., 2014: The first finding of Drusus bosnicus Group (Insecta, Trichoptera, Limnephilidae) in Croatia with some notes on diversity, distribution and ecology of genus Drusus in Croatia and in Dinaric karst of the Balkan Peninsula. Natura Croatica 23, 265-377. 
Kučinić, M., Cerjanec, D., Vučković, I., Mihoci, I., Perović, F., Kutnjak, H., Ibrahimi, H., Pelić Fixa, D., Žalac, S., Mrnjavčić Vojvoda, A. \& Plantak, M., 2015a: Some new and interesting species of caddisflies (Insecta, Trichoptera) found in Croatia. Natura Croatica 24 (2), 293-310.

Kučinić, M, Previšić, A., Graf, W., Mihoci, I., Šoufek, M., Stanić-Koštroman, S., Lelo, S., ViteceK,S. \& WARINGer, J., 2015b: Larval description of Drusus bosnicus Klapálek 1898 (Trichoptera: Limnephilidae) with distributional, molecular and ecological features. Zootaxa 3957, 85-97.

Kučinić, M., Previšić, A., Mihoci, I., Krpač, V., Živić, I., Stojanović, K., Mrnjavčić Vojvoda, A. Katušić, L., 2016: Morphological features of larvae of Drusus plicatus Radovanović (Insecta, Trichoptera) from the Republic of Macedonia with molecular, ecological, ethological, and distributional notes. ZooKeys 598, 75-97.

Malicky, H., 2004: Atlas of European Trichoptera, 359 pp. Springer, Dordrecht, Germany.

Malicky, H., 2005: Die Köcherfliegen Griechenlands. Denisia 17, 1-240.

Malicky, H., 2013: Trichoptera. Fauna Europaea version 2.6.2, http://www.faunaeur.org (accessed on 4 Juni 2016)

Malicky, H., 2014: Comments on two recently published papers on Cheumatopsyche (Hydropsychidae) and Chaetopteryx (Limnephilidae). Braueria 41, 51-53.

Malicky, H., Previšić, A. \& Kučinić, M., 2007: Rhyacophila cabrankensis nov. spec. from Croatia. Braueria 34, 14.

MATONIČKIN, I., 1959: Faunistička istraživanja reikotopnih biotopa na Plitvičkim jezerima. Ljetopis JAZU 63, 355-360.

MatoničKin, I., 1987: Građa za limnofaunu krških tekućica Hrvatske, Plitvička jeze. Biosistematika 13 (1), 25-35.

MatoničKin, I. \& PAvletić, Z., 1967: Hidrologija potočnog sistema Plitvičkih jezera i njegove ekološkobiocenološke značajke. Krš Jugosl. JAZU 5, 83-26.

MatoničKin, I., PAvletić, Z., TAvČAR, V. \& KRKač, N., 1971: Limnološka istraživanja reikotopa i fenomena protočne travertizacije u Plitvičkim jezerima. Prirodoslovna istraživanja 40, 1-68.

Morse, J. C. (Ed.), 2016: Trichoptera World Checklist. Available from:bhttp://entweb.clemson.edu/ database/trichopt/index.htm (accessed 4 June 2016)

Marinković-Gospodnetić, M., 1971: The species of genus Drusus in Yugoslavia. Godišnjak Biološkog Instituta Univerziteta (Annual of the Institute of Biology - University of Sarajevo) 23, 105-109.

Marinković-Gospodnetić, M., 1979: Trichoptera (Insecta) velikih karstnih izvora u Dinaridima. In RaUš, (ed.). Drugi kongres Ekologa Jugoslavije (Second Congress of Ecologists of Yugoslavia). Savez društava ekologa Jugoslavije, Zagreb. pp. 1837-1849.

OlÁH, J., 2010: New species and new records of Palearctic Trichoptera in the material of the Hungarian Natural History Museum. Annales Historico-Naturales Musei Nationalis Hungarici 102, 65-117.

OLÁH, J., 2011: New species and records of Balkan Trichoptera. Folia Historico Naturalia Musei Matraensis 35, 111-121.

OláH, J, \& Kovács, T., 2014: New species and records of Balkan Trichoptera III. Folia historico-Naturalia Musei Matraensis 38, 97-131.

Pauls, S.U., Blahnik, R.J., Zhou, X., Wardwell, C.T. \& Holzenthal, R.W., 2010: DNA barcode data confirm new species and reveal cryptic diversity in Chilean Smicridea (Smicridea) (Trichoptera: Hydropsychidae) Journal of the North American Benthological Society 29, 1058-1074.

PosadA, D., 2008: jModelTest: phylogenetic model averaging. Molecular Biology and Evolution 25, 12531256. 10.1093/molbev/msn083

Previšić, A., Walton, C., Kučinić, M., Mitrikeski, P. T. \& Kerovec, M., 2009: Pleistocene divergence of Dinaric Drusus endemics (Trichoptera, Limnephilidae) in multiple microrefugia within the Balkan Peninsula. Molecular Ecology 18 (4), 634-647.

Previšić, A., Graf, W. \& Kučinić, M., 2010: Caddisly (Trichoptera) fauna of the Plitvice Lakes national Park, Croatia. Denisia, 29, 287-294. 2010.

Previšić, A., Graf, W., ViteceK, S., Kučinić, M., Bálint, M., Keresztes, L., Pauls, S.U. \& Waringer, J., 2014a: Cryptic diversity of caddisflies in the Balkans: the curious case of Ecclisopteryx species (Trichoptera: Limnephilidae). Arthropod Systematics \& Phylogeny 72, 309-329.

Previšić, A., Schnitzler, J., Kučinić, M., Graf, W., Ibrahimi, H., Kerovec, M. \& Pauls, S.U., 2014b: Microscale vicariance and diversification of western Balkan caddisflies linked to karstification. Freshwater Science 33, 250-262. 
Puillandre, N., Lambert, A., Brouillet, S. \& Achaz, G., 2012: ABGD, Automatic Barcode Gap Discovery for primary species delimitation. Molecular Ecology 21(8), 1864-1877.

Radovanović, M., 1935: Trichoptere Jugoslavije. Glasnik zemaljskog muzeja u Sarajevu 47, 73-84.

Ratnasingham, S. \& Hebert, P.D.N., 2007: BOLD: The Barcode of Life Data System (www.barcodinglife. org). Molecular Ecology Notes 7, 355-364. DOI: 10.1111/j.1471-8286.2006.01678.x

Robert, B., 2015: Distribution of caddisfly species (Insecta: Trichoptera) in the Western Palearctic region. Unpublished compilation in Schmidt-Kloiber, A. \& Hering, D., 2015: www.freshwaterecology.info - an online tool that unifies, standardises and codifies more than 20,000 European freshwater organisms and their ecological preferences. Ecological Indicators 53, 271-282. doi: 10.1016/j.ecolind.2015.02.007 (accessed on 17.04.2016).

Ronquist, F. \& Huelsenbeck, J. P., 2003: MrBAYES 3: Bayesian phylogenetic inference under mixed models. Bioinformatics 19, 1572-1574.

Stanić-Koštroman, S., Kučinić, M., Kolobara, A., ŠKobić, D., Knezović, L. \& Durbešić, P., 2012: Lighttrapped caddisfliew (Insecta: Trichoptera) as indivators of the ecological integrity of the Lištica River, Bosnia and Herzegovina. Entomologica Croatica 16 (1-4), 21-36.

Stanić-Koštroman, S., Previšić, A., Kolobara, A., Kučinić, M., Š́obić, D., Dedić, A. \& Durbešić, P., 2015:Environmental determinants of contrasting caddisfly (Insecta, Trichoptera) biodiversity in the Neretva and Bosna River basins (Bosnia Herzegovina) under temperate and Mediterranean climates. International Review of Hydrobiology 100, 79-95.

ŠemničKi, P., Previšić, A., Ivković, M., Čmrlec, K. \& Minaljević, Z., 2012: Tufa Barriers from a Caddisfly's Point of View: Streams or Lake Outlets? Internat. Rev. Hydrobiol. 97, 465-484.

Tamura, K., Stecher, G., Peterson, D., Filipski A. \& Kumar, S., 2013: MEGA 6: Molecular Evolutionary Genetics Analysis Version 6.0, Mol. Biol. Evol. 30 (12), 2725 - 2729, doi: 10.1093/molbev/mst197

Villesen, P., 2007: FaBox: an online toolbox for fasta sequences, Molecular Ecology Notes 7 (6), 965-968. doi:10.1111/j.1471-8286.2007.01821.x

Vitecek, S., Graf, W., Previšić, A., Kučinić, M., Oláh, J., Bálint, M., Keresztes, L., Pauls, S.U. , WaringER, J., 2015a: A hairy case: The evolution of filtering carnivorous Drusinae (Limnephilidae, Trichoptera). Molecular Phylogenetics and Evolution 93, 249-260.

Vitecek, S., Kučinić, M., Oláh, J., Previšrć, A., Bálint, M., Keresztes, L., Waringer, J., Pauls S.U. \& Graf, W., 2015b: Description of two new filtering carnivore Drusus species (Limnephilidae, Drusinae) from the Western Balkans. ZooKeys, 513, 79-104.

Vitecek, S., Previšić, A., Kučinić, M., Bálint, M., Keresztes, L., Waringer, J, Pauls, S.U., Malicky, H. \& GrAF, W., 2015c: Description of a new species of Wormaldia from Sardinia and a new Drusus species from the Western Balkans (Trichoptera, Philopotamidae, Limnephilidae). ZooKeys 496, 85-103.

VučKović, I., Previšić, A., Graf, W. \& KučinIĆ, M., 2011: Description of the female and distribution of Annitella apfelbecki Klapálek, 1899 (Insecta: Trichoptera). Aquatic Insects 33 (4), 381-389.

Waringer, J., Graf, W., Kučinić, M., Previšić, A. \& VučKović, I., 2009: The larva and life cycle of Annitella apfelbecki Klapalek, 1899, including a re-description of Melampophylax nepos McLachlan, 1880 (Trichoptera: Limnephilidae). Aquatic Insects 30 (1), 71-80.

Waringer, J., Graf, W., Bálint, M., Kučinić, M, Pauls, S.U., Previšić, A., Keresztes, L., Ibrahimi, H., Živić, I., BJeLANović, K., KRPAČ, V. \& ViteCEK, S., 2015: Larval morphology and phylogenetic position of Drusus balcanicus, Drusus botosaneanui, Drusus serbicus and Drusus tenellus (Trchoptera: Limnephilidae: Drusinae). European Journal of Entomology 112 (2), 344-361. doi: 10.14411/eje.2015.037

Waringer, J., Previšić, A., Kučinić, M., Graf, W., Vitecek, S., Keresztes, L., Bálint, M. \& Pauls S.U., 2016: Larval morphology ofthe Western Balkans endemic caddisflies Drusus krusniki Malicky 1981, D. veronensis Malicky 1989, and D. vespertinus Marinković-Gospodnetić 1976 (Trichoptera, Limnephilidae, Drusinae). Zootaxa 4083, 483-500.

Zhou, X., KJer, K.M. \& Morse, J.C., 2007: Associating larvae and adults of Chinese Hydropsychidae caddisflies (Insecta:Trichoptera) using DNA sequences. Journal of the North American Benthological Society, 26, 719-742. 10.1899/06-089.1.

Zноч, X., 2009: The larvae of Chinese Hydropsychidae (Insecta: Trichoptera), Part I: Arctopsyche shimianensis, Parapsyche sp. A, and Diplectrona obscura. Zootaxa 2174, 1-17. 


\title{
SAŽETAK
}

\section{Prvi nalaz Tinodes antonioi Botosaneanu \& Taticchi-Viganò, 1974 (Insecta, Trichoptera) u Hrvatskoj s DNA barkod i ekološkim podacima i noticom na bioraznolikost i rasprostranjenost roda Tinodes u Hrvatskoj}

\author{
M. Kučinić, A. Ćukušić, M. Podnar, M. Landeka, H. Plavec, M. Plantak, \\ N. Akimbekova \& S. Žalac
}

Vrsta Tinodes antonioi, zabilježena je po prvi puta kao nova u fauni Hrvatske u sjevernoj Istri, na dva lokaliteta (potoci Mlini i Marušića potok). U radu se daju informacije o T. antonioi u Hrvatskoj (DNA barkod podaci, periodi nalaza, lokaliteti nalaza, broj prikupljenih mužjaka i ženki), kao i bioraznolikost i rasprostranjenost roda Tinodes u Hrvatskoj. Rod Tinodes zastupljen je u fauni Hrvatske s 8 vrsta, od kojih 4 dolazi u panonskoj-peripanonskoj, 5 u gorskoj, a 6 u mediteranskoj Hrvatskoj. Daje se osvrt i na Tinodes andrasi, endemske vrste tulara, zabilježenu samo na jednom lokalitetu u Hrvatskoj (Konavle, Dalmacija). 